\title{
Microscopic variability in mechanical defence and herbivory response in microphyllous leaves of tropical herb species from Serra do Cipó, Brazil
}

\author{
SÉRVIO PONTES RIBEIRO ${ }^{1,3}$, TATIANA LOPEZ CORRÊA ${ }^{1,2}$ and \\ HILDEBERTO CALDAS DE SOUSA ${ }^{2}$
}

(received: December 11, 2008; accepted: March 18, 2010)

\begin{abstract}
Microscopic variability in mechanical defence and herbivory response in microphyllous leaves of tropical herb species from Serra do Cipó, Brazil). Tropical high altitude grasslands present several species with both microphyllous and highly sclerophyllous leaves, and co-occur in specific soil patches, thus exposed to identical environments. In this article we describe herbivory among co-occurring microphyllous species in a tropical high altitude grassland ecosystem of Serra do Cipó, Minas Gerais state, and we tested the effect of variable anatomic traits on leaf herbivory patterns. Leaf anatomical traits were investigated for Baccharis imbricata Heering, Lavoisiera imbricata DC. and L. subulata Triana (focal species). Herbivory was measured from branches and leaves of individual plants and compared among co-occurring species within one multispecific shrub patch and among $L$. subulata individuals from this patch and an adjacent monospecific patch. For all present plant species and individuals we estimated the proportion of leaves with different levels of area lost. For the focal species, six leaves were sorted and taken for histological sectioning, in order to allow precise measures of defensive structures. Relative mean leaf area lost differed significantly among the six species found in the multispecific patch. Lavoisiera subulata individuals were more attacked in the multispecific than in the monospecific patch. Leaf margin protection traits in both B. imbricata and L. imbricata showed significant effect against herbivory. Data suggest that some anatomic traits have direct effect against herbivory but their effect are not clearly perceptible among branches within individual plants or among plants within the same species.
\end{abstract}

Key words - Asteraceae, fibres, insect-plant interaction, Melastomataceae, sclerophylly

RESUMO - (Variabilidade microscópica em defesa mecânica e resposta à herbivoria em folhas micrófilas de espécies herbáceas tropicais da Serra do Cipó, Brasil). Campos de altitude tropicais apresentam várias espécies com folhas micrófilas e altamente esclerófilas que co-ocorrem em manchas de solo específicas e, portanto, expostas a ambientes idênticos. Neste artigo, foi descrita a herbivoria entre espécies micrófilas co-ocorrendo em um ecossistema tropical de campos de altitude na Serra do Cipó, Minas Gerais, e testado o efeito de caracteres anatômicos variáveis no padrão de herbivoria foliar. Os caracteres anatômicos das folhas foram investigados em Baccharis imbricata Heering, Lavoisiera imbricata DC. e L. subulata Triana (espécies em foco). A herbivoria foi medida nos ramos e nas folhas de cada planta coletada e comparada entre as espécies estudadas em uma mancha multiespecífica e entre os indivíduos de $L$. subulata da mesma mancha e de uma mancha monoespecífica adjacente. Para todas as espécies e indivíduos foi estimada a proporção de folhas com diferentes níveis de área perdida. Para as espécies em foco, seis folhas foram sorteadas e submetidas a cortes histológicos com o objetivo de realizar medidas precisas das possíveis estruturas anatômicas de defesa. A média relativa de área foliar perdida diferiu significativamente entre as seis espécies encontradas na mancha multiespecífica. Indivíduos de L. subulata foram mais atacados na mancha multiespecífica que na mancha monoespecífica. Os caracteres anatômicos de proteção marginal tanto em B. imbricata quanto em L. imbricata apresentaram um efeito significativo contra a herbivoria. Os resultados sugerem o fato de alguns caracteres anatômicos terem efeito direto contra a herbivoria, mas seu efeito não é claramente perceptível entre os ramos de uma mesma planta ou entre plantas de uma mesma espécie.

Palavras-chave - Asteraceae, esclerofilia, fibras, interação inseto-planta, Melastomataceae

\section{Introduction}

Herbivory pressure may affect species evolution, plant population dynamics and influences adaptations

1. Universidade Federal de Ouro Preto, Debio/Instituto de Ciências Exatas e Biológicas, Laboratório de Ecologia de Insetos de Dossel e Sucessão Natural, Campus Morro do Cruzeiro, Bauxita, 35400-000 Ouro Preto, MG, Brazil.

2. Universidade Federal de Ouro Preto, Debio/Instituto de Ciências Exatas e Biológicas, Laboratório de Anatomia Vegetal, Campus Morro do Cruzeiro, Bauxita, 35400-000 Ouro Preto, MG, Brazil.

3. Correspondance author: spribeiro@iceb.ufop.br to certain environmental conditions. Individual plants which are more resistant against insect feeding may be favoured in terms of growth, reproduction, and therefore competitive capabilities, both intra and interespecifically (Herms \& Mattson 1992, Crawley 1997). Hence, many plant tissues structures may have evolved in order to constrain insect feeding activities (Price 1984). Physical barriers related to high content of fibres (sclerenchyma), lignins, and crystals (mainly calcium oxalate and carbon polymers exudates) can add up to low nutritional leaf quality in plants adapted to tropical poor soils, as a by-product of the typical leaf sclerophylly of such plants 
(Loveless 1962, Gershenson 1984). Sclerophyllous plants support low numbers of insect herbivore species, particularly generalists species (Ribeiro et al. 1998, 1999), but can be severely attacked by few specialist herbivore insects (Ribeiro et al. 1994, Ribeiro 2003).

Low availability of phosphate and nitrogen in the soil along with continuing photosynthesis in the tropics increases the level of sclerophylly due to a proportionally greater carbon income, thus resulting in accumulation of carbon polymers, such as polyphenols (Gershenzon 1984, Haslam 1988, Herms \& Mattson 1992, Turner 1994a, Ribeiro et al. 1999). Most carbon-based secondary compounds accumulated during plant growth act as anti-herbivore defences (Feeny 1976, Bernays et al. 1989). Moreover, many external leaf structures accumulate carbon polymers (Woodman \& Fernandes 1991, Ribeiro et al. 1994).

Regardless any biochemical causes, leaf sclerophyllous texture itself is a by-product of foliar anatomy. Cuticle chemical composition, width of external epidermic walls, and a great amount of fibres surrounding vascular vessels and in leaf margins are typically related to the discernment of a sclerophyllous leaf (Esau 1977, Fahn 1990). Such traits are also related to leaf life span, being sclerophyllous leaves generally longevous (Coley \& Aide 1991, Reich et al. 1991).

Another aspect of insect-plant interaction hardly explored in recent literature is the role of leaf ontogeny in producing protective strategies. Herbivory tends to increase during leaf expansion phase, which might be related to low concentration of secondary compounds (Feeny 1970, Coley 1983, Lowman \& Box 1983). Therefore, reduction in the period of leaf expansion may protect the plant against insect attack. Moles \& Westoby (2000) have shown that plants with shorter expansion periods must have smaller leaves too, which may bring further defensive advantages. Ribeiro et al. (1994) showed that specialist leaf herbivores feeding on Tabebuia ochracea (Cham.) Standl. (Bignoniaceae) choose to be in larger than smaller leaves, independently of leaf age. This plant has a great leaf area variation within and among leaf cohorts, and the authors demonstrated that the insect choices were related to the density of trichomes, which was lower in larger leaves.

Many other authors have pointed out mechanisms that seem to influence a positive choice for large leaves and vigorous plants (Feeny 1976, Whitham \& Slobodchikoff 1981, Whitham 1983, Price 1991). Conversely, the relationship between insect herbivory pressure and evolution of true microphyllous traits in many species is not clear. A great deal of confounding evolutionary causes may result in microphylly, particularly in sclerophyllous vegetation. Nevertheless, combined effects of leaf sclerophylly and defensive anatomic traits, as is the case of complex trichomes that contain high contents of polyphenols (Ribeiro et al. 1999), may be better perceived in very small leaves (Pyykko 1966, Giulietti et al. 1987, Fahn \& Cutler 1992). Recently, studies in the Azorean oceanic islands have shown the importance of microphyllous traits of dominant tree species in defining herbivory patterns and in shaping habitats for insect herbivore community (Ribeiro et al. 2003, 2005).

The vegetation of the Serra do Espinhaço, in south-eastern Brazil, is dominated by sclerophyllous species. Sclerophylly is a widespread trait in most plant species found in the best preserved spot of these mountains, the Parque Nacional da Serra do Cipó. Sclerophylly in this ecosystem is characterized by high concentration of polyphenol compounds in plant leaves, irrespective of studied habitat (Madeira et al. 1998, Ribeiro et al. 1999). Whether herbivory occurs at various rates (tending to high), herbivore species happens in low density (Ribeiro et al. 1998, 1999). Mostly important, leaf traits of some studied species suggest adaptive responses against damage. For instance, a great amount of fibres in the margins and at the cortical region of the abaxial surface near the midrib of Lavoisiera species, along with high accumulation of polyphenol compounds (Sousa 1997) show a certain anatomic organization of the carbon-based polymers that suggest anti-herbivore functions (see Howe \& Westley 1988, Salatino 1993, Panda \& Naush 1995). Many species in this vegetation co-occur in small patches, apparently restricted by soil or water conditions. These plants tend to present morphologic convergence, namely imbricatad and reduced leaf size (hereafter termed microphylly), and related sclerophyllous structures or fibres organization (Handro et al. 1970, Monteiro et al. 1985). Evolutionary causes of these convergences are not fully understood.

In this article we describe the overall herbivory in one monospecific and one multispecific patch of microphyllous shrub species found in a tropical high altitude grassland ecosystem. We objective to describe variation in microscopic plant mechanical defences, and their effects on herbivory within and among species. In this regard, we tested the hypothesis that herbivory patterns respond to the presence of some anatomic characters linked to mechanical defences. We predict that herbivory varies among species and individual plants negatively correlated with the number of defensive traits and with quantitative leaf components, such as thickness 
of fibre strands, size of tissues with tannins, number of glandular trichomes, or secretory ducts.

We also tested the hypothesis that herbivory differs among plant populations of $L$. subulata in a monospecific versus a multispecific patch. Our prediction is that in this small scale, in which the host plants population is extremely patchy distributed, population density may favour specialist insects, which are an important cause of leaf damage in sclerophyllous vegetation (Fernandes \& Price 1988, Ribeiro 2003).

\section{Material and methods}

Study site - Study populations were found at 1,300 m above sea level, in the Serra do Espinhaço, in the buffer zone of the Parque Nacional da Serra do Cipó, Minas Gerais State, south-eastern Brazil (19¹2' $-19^{\circ} 20^{\prime} \mathrm{S}$ and $43^{\circ} 30^{\prime}-43^{\circ} 40^{\prime} \mathrm{W}$ ). This is a high altitude grassland ecosystem composed of vegetation types dominated by grasses, with well-defined patches of sclerophyllous and xeromorphic shrub plant species, associated with quartzite rocky spots, or with differential soil/water conditions. The regional climate regime is mildly seasonal, with temperature varying from $17.4{ }^{\circ} \mathrm{C}$ to $19.8^{\circ} \mathrm{C}$ in summer, and annual rain precipitation around $1,500 \mathrm{~mm}$, concentrated over seven-to-eight wet months, from September to April (Galvão \& Nimer 1965). Patches of shrub species were chosen within a same location on shallow sandy, quartzite soils, close to the flooding margins of a small affluent of the creek Capivara.

Studied species and sampling design - One multispecific patch with six species and one monospecific patch of Lavoisiera subulata were studied (table 1). The most frequent family in the multispecific patch was Melastomataceae. In March 2001, thus by the end of the rainy season, a full plant census was done in the multispecific plant patch. All individuals were included in a study for general patterns of leaf damage by herbivory, totalling 68 individuals. In the nearby monospecific patch of $L$. subulata, 15 randomly chosen individuals were marked and sampled. The table 1 summarizes the sample size per plant species. In order to describe herbivory in the whole sampled patch, the two Lavoisiera species and Baccharis imbricata (hereafter focal species) were compared separately to all other species (grouped together due to small numbers or imprecise taxonomic description). Hence, detailed anatomic analyses of herbivory and leaf defence, to test the present hypotheses, were performed only for these three focal species. From each sampled individual, three random branches were sampled for analyses of herbivory and determination of anatomic traits related to plant defence. Voucher specimens (B. imbricata - OUPR 16.245, L. imbricata - OUPR 9762 and $L$. subulata - UEC 066.867) were deposited in the herbarium José Badini (OUPR) of the Universidade Federal de Ouro Preto, Minas Gerais, Brazil and herbarium of the Universidade Estadual de Campinas (UEC), São Paulo,
Brazil. The following variables were used to quantify leaf damage: 1 ) proportion of damaged leaves (= any leaves with area lost by herbivory above 5\%) per branch leaves; and 2 ) percentage of leaf area lost, which was sub-divided into classes (1: 0-10\%; 2: 11-90\% and 3: 91-100\%). These broad classes are justified due to the extremely small leaf sizes (3-6 mm length). Types of damage were also divided into three groups: 1) Chrysomelid beetles chewing, which was identified as scratches on the surface of the leaf, grouped in small spots (caused mainly by unidentified species of Eumopinae observed on the leaves); 2) leaf border chewing, caused mainly by Lepidoptera species (larvae of unidentified Geometrid species observed on the plants) and 3) unidentified generalists, or infrequent specialist insect species of various orders. Values of herbivory were analysed as follows:

Proportion of damaged leaves (Pdl):

$$
\mathrm{Pdl}=\sum \frac{L_{d}}{L_{t}}
$$

Where $L_{d}$ is the number of damaged leaves and $L_{t}$ is the total leaves per all sampled branch for each plant.

Relative mean leaf area lost (Rmlal):

$$
\text { Rmlal }=\sum \frac{\left(L_{d i} \times \bar{A}_{l i}\right)}{L_{d}}
$$

Where $L_{d i}$ is each leaf counted belonging to the area lost class $\mathrm{i} ; \bar{A}_{l i}$ the mean value for each class (being 1 : $5 \%$; 2 : $50.5 \%$ and 3: $95.5 \%$ ); and $L_{d}$ is the total number of damaged leaves.

For studying leaf damage in response to leaf anatomic traits, a sub-set of five individuals of each focal species was taken and from them two branches: one with most leaves damaged and one with little damaged leaves. From each branch leaves were randomly taken until complete five undamaged leaves and five variously damaged leaves, then fixed in aqueous solution, containing 5\% formalin and $10 \%$

Table 1. Species sampled in multispecific and monospecific patches.

\begin{tabular}{lc}
\hline Multispecific patch & $\begin{array}{c}\text { Number of } \\
\text { samples }\end{array}$ \\
\hline Baccharis imbricata Heering (Asteraceae) & 30 \\
Lavoisiera imbricata DC. (Melastomataceae) & 25 \\
Lavoisiera subulata Triana (Melastomataceae) & 5 \\
Marcetia taxifolia (A. St.-Hil) DC. & 1 \\
$\quad$ (Melastomataceae) & 1 \\
Microlicia sp. (Melastomataceae) & 6 \\
Non-identified species of Lythraceae & \\
$\quad$ monospecific patch & \\
Lavoisiera subulata Triana (Melastomataceae) & 15 \\
\hline
\end{tabular}


ferrous sulphate for 48 hours (Johansen 1940). The material was kept in $70 \%$ glycerinate ethylic alcohol.

A further study explored at the leaf level the co-occurrence of defensive traits and herbivory. A sample of 150 leaves was drawn in camera lucida on a millimetre paper to allow precise measure of external structures, leaf area lost, and record of herbivory types. The leaf surface structures measured by this mean were 1) mean width of marginal fibres band (taken from random measures on five sites in both halves of the leaf) in L. imbricata; and 2) number of teeth in serrated leaves and leaf asymmetry for $B$. imbricata (number of teeth in one margin subtracted from the number in the other). In L. subulata no leaf surface structures were identified.

Anatomic defensive traits - From these 10 drawn leaves per plant individuals, histological sections were made for three damaged and three undamaged leaves to describe defensive structures, summing up 90 sectioned leaves. After preliminary prospecting for the presence of such structures, the anatomy of each plant species was analysed in detail. The leaf anatomy of these species will be published elsewhere, but measures of quantitative traits and the presence of qualitative, potentially defensive traits, are reported in this article. Hand-cut transverse sections were taken from midlamina region of the leaf and mounted in semi-permanent slide with $50 \%$ glycerine. Histochemical tests were made with Sudan III (Sass 1951) to explore the nature of contents from secretory ducts of $B$. imbricata. Dissociation of leaf epidermis (Johansen 1940) was done in L. imbricata, to confirm the presence of glandular trichomes in the basis of tector emergences in leaf margins and midrib (see Sousa, 1997) in specimens. In addition, leaf diaphanousness treatment (Foster 1953) was applied to L. imbricata (aiming visualization of leaf margin and midrib strands of fibres) and to $B$. imbricata (to confirm the absence of glandular trichomes in the basis or in the extremities of marginal leaf teeth). Anatomic measures and photomicrography (40x amplification and photographs at various amplifications, mostly between 20x e 40x) were done in a photomicroscope
Leica DMLS 30 with micrometric lens. Figure 1 A-C shows a schematic drawing of the leaf transverse sections and table 2 summarizes the structures studied per species. Fibre strands area cover in a leaf was estimated based on the summing up of best fit of geometric forms that matches each drawn segment of the strand (Lima 1991). Width marginal fibres band were measured with digital Vernier calipers (Digimess $150 \mathrm{~mm} / 6$ inches - Shinko Precision Gaging Ltd.). Hickey's (1979) leaf margin classification was adopted in this work.

Statistical analyses - To test the hypothesis that leaf area lost differs among studied species, we used ANCOVA model, in which plant species as well as plant height were tested as fixed factors and covariate, respectively. ANOVA was also used to compare individuals of $L$. subulata between multispecific and monodominant patches. In these models the taxonomic level of species was considered an acceptable phylogenetic treatment. We assumed therefore that defences evolved independently between them, regardless of the closer taxonomic relation among Melastomataceae species versus Asteraceae and Lythraceae. Percentage of leaf area lost was arc sine transformed to match assumptions of normality and compared by univariate ANOVA (Zar 1996). The assumption here is that acceptance of the null hypothesis (i.e., there is similar and low herbivory among microphyllous species) means adaptive convergence or equivalent ecological pressures. Simple linear regression was used to test if herbivory levels could be correlated with anatomic characters, in within-species analyses. Each drawn leaf in the camera lucida was taken as an independent replicate for this analysis, to test the effect of leaf measures regardless of any genetic background among leaves. Therefore, we assumed that the original plant was less important than the exact measure of defensive trait of each leaf, considering that we tested the hypothesis at the leaf level. Each histological character was tested as variable for leaf area lost in simple linear regressions models. The following anatomical traits were tested as explanatory variables in simple linear regression models per each host species: 1) B. imbricata - Mean width of outer

Table 2. Selected anatomic parameters measured on the three studied species.

\begin{tabular}{lccc}
\hline \multirow{2}{*}{ Measures } & \multicolumn{3}{c}{ Species } \\
\cline { 2 - 4 } & B. imbricata & L. imbricata & L. subulata \\
\hline $\begin{array}{c}\text { Mean width of outer periclinal wall of the epidermal } \\
\text { cells in both leaf surfaces }\end{array}$ & $\mathrm{X}$ & $\mathrm{X}$ & $\mathrm{X}$ \\
$\begin{array}{c}\text { Mean width of outer periclinal wall of the epidermal } \\
\text { cells close to the midrib fibres strands }\end{array}$ & - & $\mathrm{X}$ & - \\
Marginal leaf teeth in serrated leaves & & & - \\
Mean width of marginal fibres band & $\mathrm{X}$ & $\mathrm{X}$ & - \\
Mean area of the fibres strands in the midrib & - & $\mathrm{X}$ & $\mathrm{X}$ \\
Mean area of the marginal fibres band & $\mathrm{X}$ & $\mathrm{X}$ & - \\
Crystalliferous idioblasts $\mu \mathrm{m}^{-2}$ & - & $\mathrm{X}$ & $\mathrm{X}$ \\
Secretory ducts & - & - & - \\
\hline
\end{tabular}


A

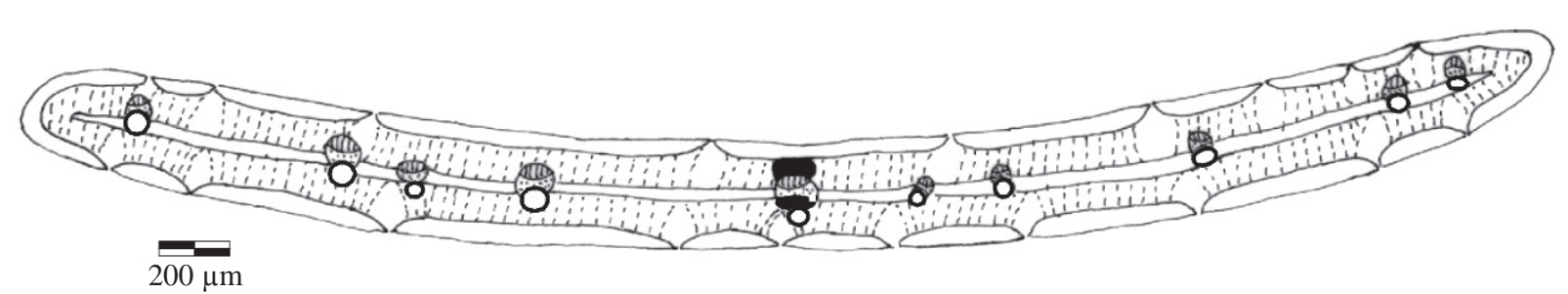

B

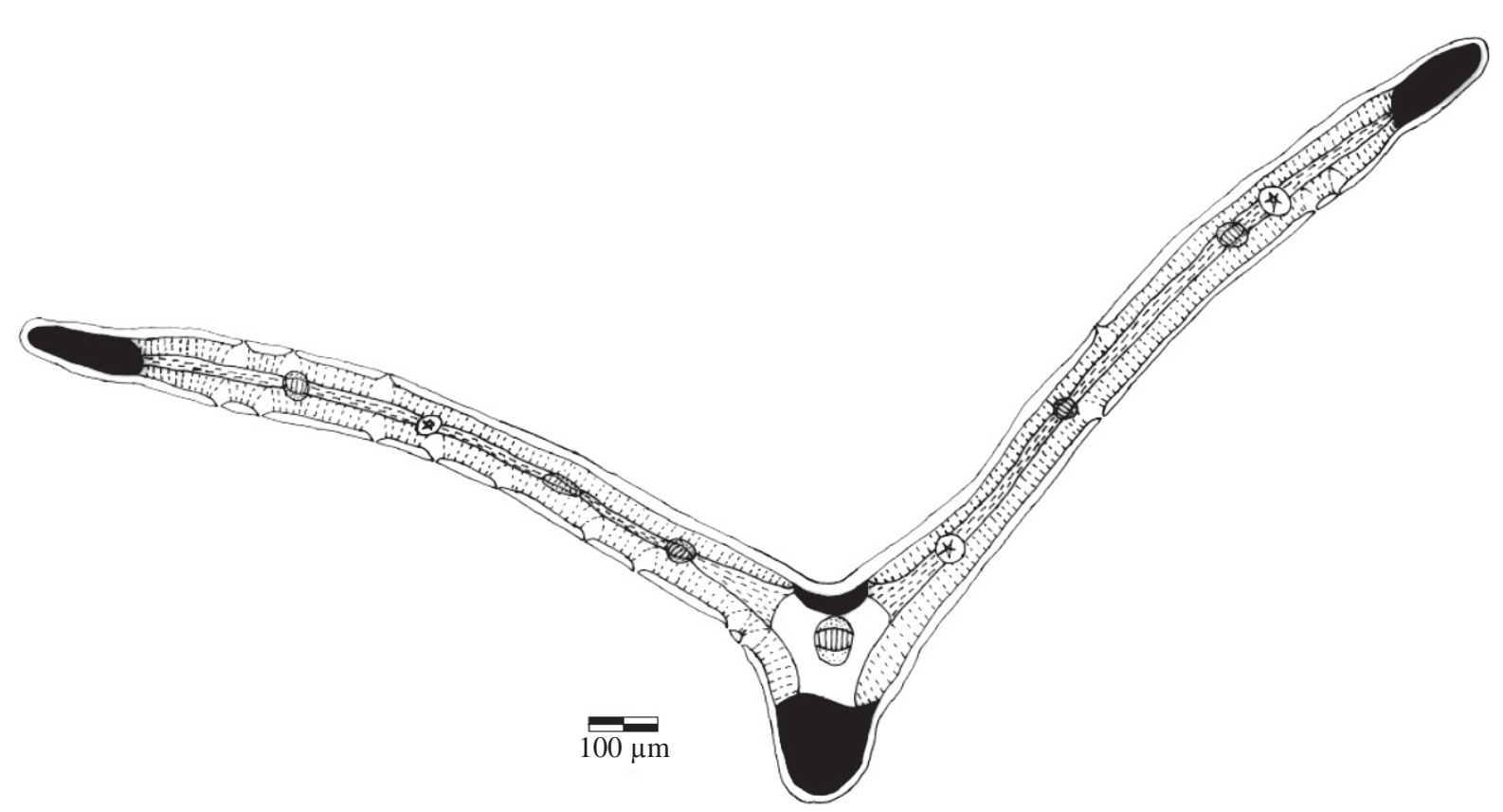

C

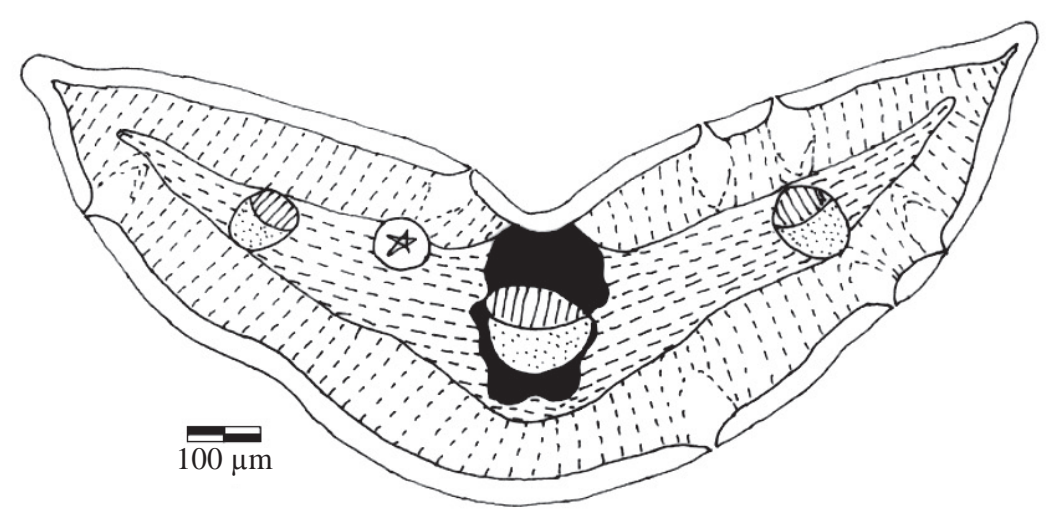

Figure 1. Schematic drawing of the leaves in transverse section. A. Baccharis imbricata B. Lavoisiera imbricata. C. L. subulata. (四 = Xylem; 䧃 = Phloem; $\square=$ Epidermis, Parenchyma tissue, Sub-stomatal chamber; . - = Sclerenchyma; $\downarrow$ = Druses; $O=$ Secretory ducts).

periclinal wall of the epidermal cells (both leaf surfaces), numbers of marginal leaf teeth (non fibrous structures), mean area fibre strands in the midrib and the number of secretory ducts per square micrometer in mesophyll; 2) L. imbricata - Mean width of outer periclinal wall of the epidermal cells (both leaf surfaces), mean width of the outer periclinal wall of the epidermal cells close to the midrib fibres strands, mean width of marginal fibre bands, mean area of fibre strands in the midrib, mean area of the marginal fibre band and the number of crystalliferous idioblasts per square micrometer; 3) L. subulata - Mean width of outer periclinal wall of the epidermal cells, in both leaf surfaces, mean area of the fibres 
strands in the midrib and the number of crystalliferous idioblasts per square micrometer.

\section{Results}

The relative mean leaf area lost by herbivory was high, varying from $36 \%$ in B. imbricata to $20 \%$ in L. subulata. For instance, relative mean leaf area lost (Rmlal) differed significantly among the three focal species and all the others species grouped together $\left(\mathrm{F}_{3 ; 67}=8.45 ; P<0.0001\right.$; Tukey test, figure 2$)$, but there was no influence of the covariate plant height $\left(\mathrm{F}_{3 ; 67}=0.02 ; P>0.05\right)$.

In addition, $L$. subulata individuals were significantly more attacked in the multispecific than in the monospecific patch, taking in consideration the proportion of damaged leaves $\left(\mathrm{F}_{1 ; 53}=18.75 ; P<0.001\right.$; figure 3).

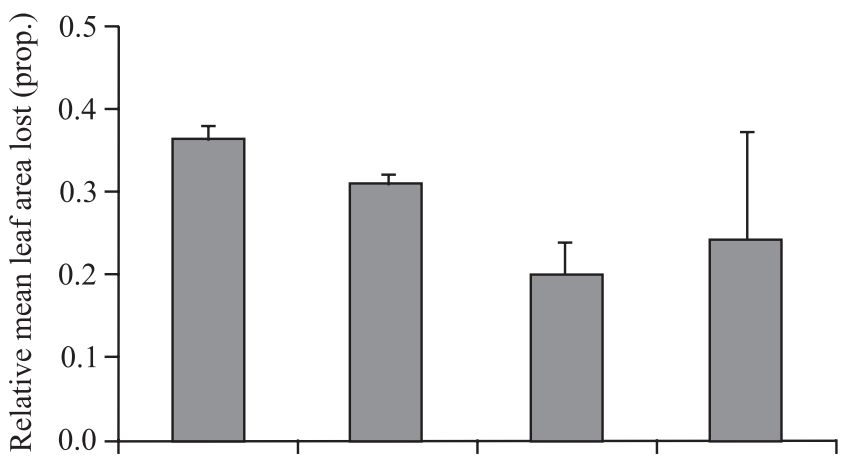

$\begin{array}{lll}\text { B. imbricata L. imbricata } \quad \text { L. subulata others species } & \end{array}$

Figure 2. Relative mean leaf area lost (Rmlal) in Baccharis imbricata, Lavoisiera imbricata, L. subulata, and all other species censured together (Lythraceae, M. taxifolia and Microlicia sp.), at Serra do Cipó, MG $(P<0.05)$ (mean \pm standard deviation).

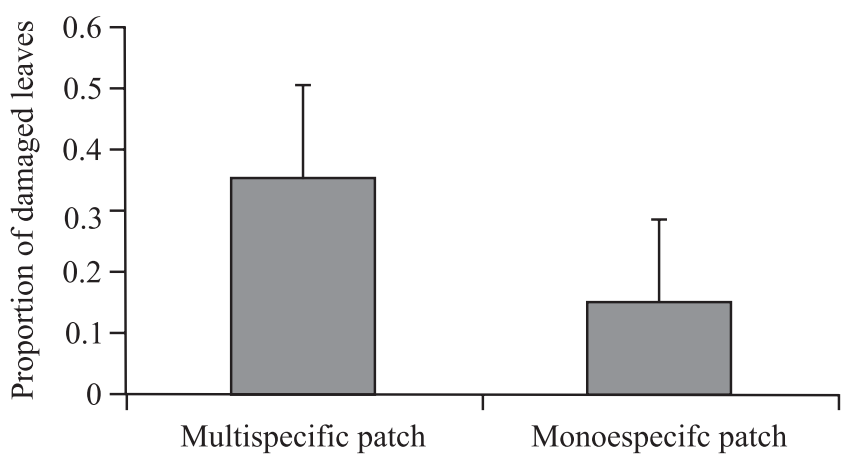

Figure 3. Proportion of damaged leaves (Pdl) in the multispecific and monospecific populations of Lavoisiera subulata (mean \pm standard deviation).
Proportion of leaf area lost varied marginally among the three focal species: L. imbricata was less attacked than B. imbricata and L. subulata species $\left(\mathrm{F}_{2 ; 12}=3.69\right.$; $P<0.056$; Tukey test, figure 4). Most leaf damage found in these species was caused by herbivores that eat from the margins, such as grasshoppers and lepidopterans, but a small amount of damage was caused by the non-identified species of Eumopinae. Only B. imbricata had no Eumopinae damage.

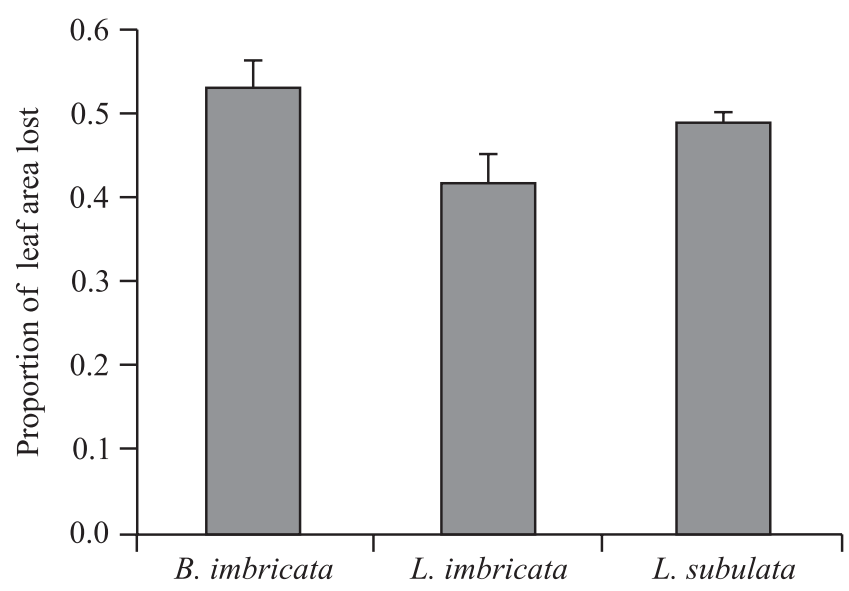

Figure 4. Proportion of leaf area lost in Baccharis imbricata, Lavoisiera imbricata and L. subulata at Serra do Cipó-MG. Different letters indicate statistically significant differences $(P<0.05)$ (mean \pm standard deviation).

Data suggest that anatomic traits related to leaf margin protection may be more effective against herbivory than other mechanical defences spread in the leaf lamina, as margin attack is likely to be a major biotic selective force on these plant community. In agreement, L. imbricata was the species with the larger number of anatomic traits in the margins and also the one with the smallest leaf area lost by herbivory among the studied plants (table 2, figure 5). Conversely, B. imbricata presented less margin defensive traits, and also one leaf teeth which is not fibrous, thus possibly less effective as an overall defence, even though some within-species negative effect on herbivory was found (see below).

Within-species analyses corroborate the hypothesis that leaf margin anatomic traits have direct effect against herbivory. For instance, proportion of leaf area lost in $B$. imbricata decreases significantly with increasing number of marginal leaf teeth $(\mathrm{y}=0.67-0.023 \mathrm{x}$; $\mathrm{F}_{1 ; 48}=10.93 ; P<0.05$; figure 6 ), which resulted in plants been differently attacked $\left(\mathrm{F}_{1 ; 4}=6.41 ; P<0.05\right)$. On the contrary, the direct effect of mean width of outer 


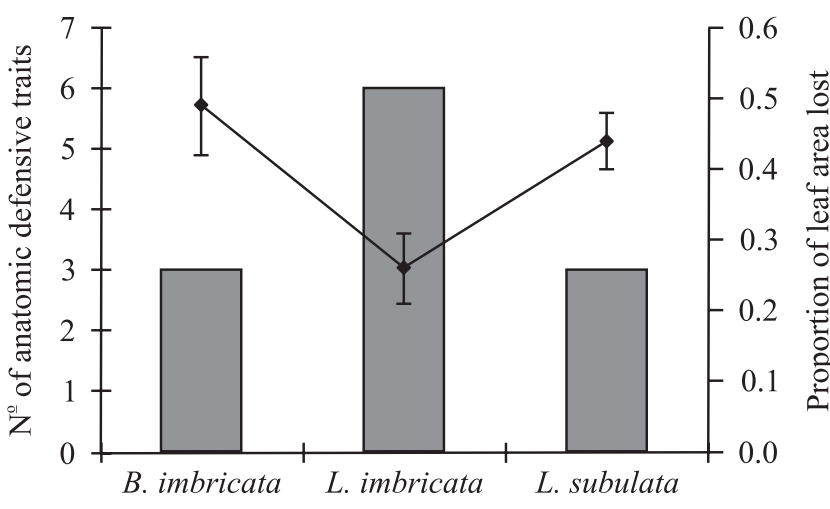

Figure 5. Relation between the number of anatomic defensive traits $(\square)$ and the proportion of leaf area lost $(\bullet-)$ in Baccharis imbricata, Lavoisiera imbricata and L. subulata (mean \pm standard deviation).

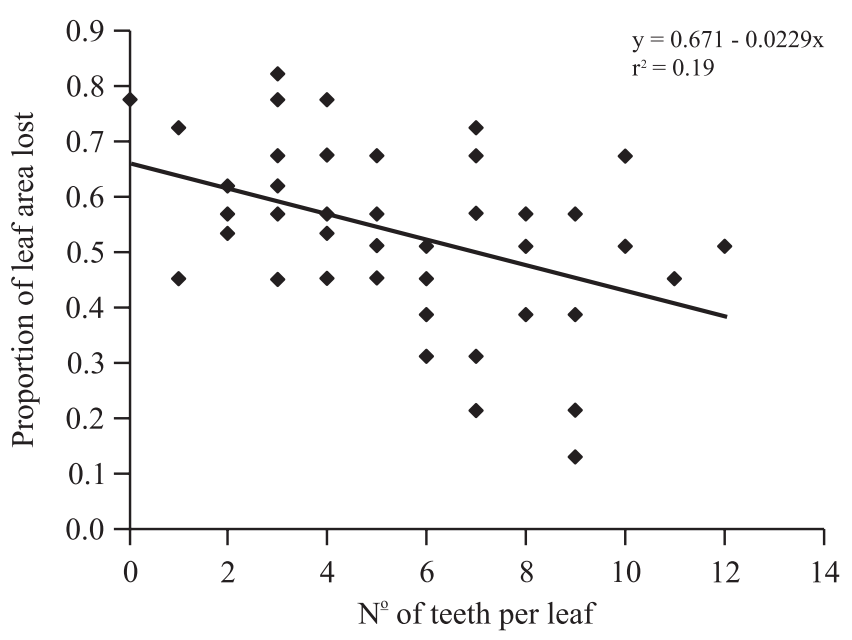

Figure 6. Effect of number of teeths per leaf on the proportion of leaf area lost of Baccharis imbricata.

periclinal wall of the epidermal cells in both leaf surfaces $\left(\mathrm{F}_{1 ; 28}=1.05 ; P>0.05\right)$, mean area of the fibre strands in the midrib $\left(\mathrm{F}_{1 ; 28}=1.00 ; P>0.05\right)$ and number of secretory ducts $\left(\mathrm{F}_{1 ; 28}=0.27 ; P>0.05\right)$ on herbivory rates could not be detected.

Herbivory decreased in L. imbricata in response to mean width of outer periclinal wall of the epidermal cells close to the midrib fibres strands ( $y=0.98-0.023 x$; $\left.\mathrm{F}_{1 ; 23}=4.42 ; \mathrm{r}^{2}=0.16 ; P<0.05\right)$ and mean area of marginal fibres band $\left(\mathrm{y}=0.75-2 \mathrm{E}-05 \mathrm{x} ; \mathrm{F}_{1 ; 28}=7.03\right.$; $P<0.05$; figure 7). On the other hand, the direct effect of mean width of outer periclinal wall of the epidermal cells in both leaf surfaces $\left(\mathrm{F}_{1 ; 28}=0.43 ; P>0.05\right)$, mean width of marginal fibres band $\left(\mathrm{F}_{1 ; 28}=1.45 ; P>0.05\right)$, mean area of the fibre strands in the midrib $\left(\mathrm{F}_{1 ; 22}=0.33\right.$; $P>0.05)$ and the number of crystalliferous idioblasts per

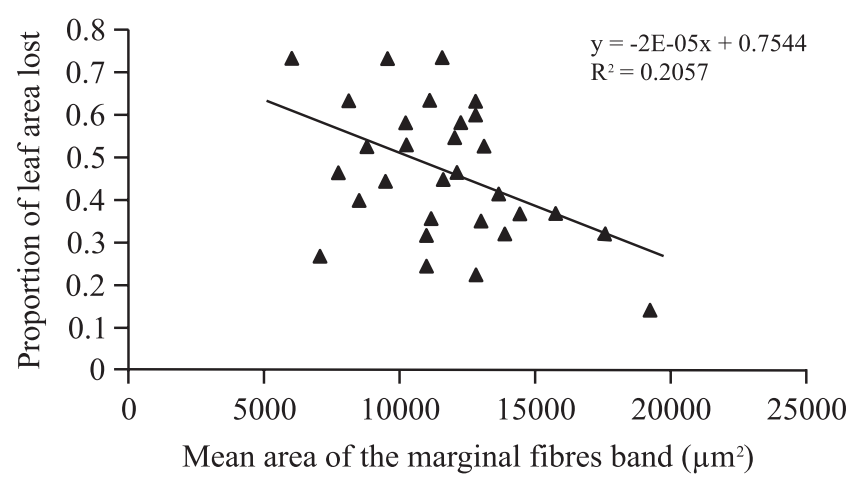

Figure 7. Effect of the mean area of the marginal fibres band on the proportion of leaf area lost of Lavoisiera imbricata.

square micrometer $\left(\mathrm{F}_{1 ; 28}=0.13 ; P>0.05\right)$ on herbivory rates were not statistically significant.

Likewise, in L. subulata there were no significant effect of the mean width of outer periclinal wall of the epidermal cells in both leaf surfaces $\left(F_{1 ; 28}=0.01\right.$; $P>0.05$ ), and the number of crystalliferous idioblasts per square micrometer $\left(\mathrm{F}_{1 ; 28}=0.06 ; P>0.05\right)$ on herbivory rates, but the mean area of fibre strands in the midrib showed a positive correlation with the proportion of leaf area lost $\left(\mathrm{y}=0.29+2 \mathrm{E}-05 \mathrm{x} ; \mathrm{F}_{1 ; 28}=4.31 ; P<0.05\right)$. This result indicates that the type of fibres observed in $L$. subulata is inefficient in causing leaf toughness.

\section{Discussion}

The studied species suffered relatively high insect attack compared with wet tropical plant communities, although this pattern was similar to previous data of herbivory in cerrado vegetation (Ribeiro 2003), and in dry forests (Coley \& Barone 1996). Such plant communities may support up to $14-18 \%$ average annual leaf area lost, above global average (around 10\%) but in long-term studies (see Lowman 1995a, b, Schowalter \& Lowman 1999, Rinker \& Lowman 2004), the herbivory monitoring and measurements are more accurate and invariably higher than in short-term measurements. Ribeiro et al. (1999) states the hypothesis that sclerophyllous vegetation support little herbivore species diversity. However, those insects are expected to be specialist to the harsh environmental conditions of these habitats, and thus one or two species may cause extensive damage on their host species, despite deterrence of this vegetation (see also Fernandes 1994).

Insect damage was inversely related to the number of defensive anatomical traits per plant species, even though the direct effect of some of these structures could 
not be detected. Low nutritional quality may confound with the effect of each specific defence, although they still can act strongly against specialist insects, as suggests the observed negative effect of fibres strands and external periclinal wall of epidermic cells width, or number of margin teeth. Sclerophyllous leaves are nutritionally poor due to the high rate $\mathrm{C} / \mathrm{N}$ (Loveless 1962), which results in high concentration of fibres, trichomes and phenolic compounds, and thick epidermic cell walls (Salatino 1993, Turner 1994b). Low herbivore insect activity has been reported on high altitude grasslands of Serra do Cipó (Ribeiro et al. 1998), and particularly on Melastomataceae species, at several altitudes and habitat conditions (Ribeiro et al. 1999).

The studied species had several anatomic traits that clearly act as mechanic defence, particularly in external tissues (table 2). As described above, the more a plant accumulates defensive structures, the less it was damaged by herbivory.

The location of fibres in both $B$. imbricata and L. subulata are suggestive of protective function. Fibres in the margins or around the midrib, in both the adaxial or abaxial cortical region near xylem or phloem, respectively, can clearly limit the access of herbivores to the conductive tissues. On the other hand, fibres around the midrib in dicotyledons are inefficient as mechanic support (Lucas et al. 2000). Moreover, the amount of fibres found is considerably large for a microphyllous leaf, which should require little energy to keep itself sustained unbent.

Regardless their effect on the elasticity and other traits related to mechanic resistance (Lucas et al. 2000), an important aspect related to a large proportion of fibres in a leaf is the increasing of toughness, which clearly the primary herbivory deterrent trait of a plant. Nevertheless, some anatomic details seem to indicate the relative importance of fibre structure variation among species and their efficiency as a defensive trait.

Baccharis imbricata has adaxial surface epidermic cells twice as high as those of $L$. subulata and three times higher than L. imbricata. In addition, external and internal adaxial surface periclinal walls were thicker than those of other species, which reflect greater accumulation of fibres. However, B. imbricata is the most attacked species, which seems to be related to fewer defensive anatomic structures, but also to a certain level of inefficiency of its leaf fibres in causing leaf toughness. Considering that its cells might be composed by less complex fibres, it could result in leaves with greater physical resistance and elasticity, but smaller toughness (Lucas et al. 2000). It is important to note that Baccharis sp. is a pioneer species, and thus may invest more in fast growth and reproduction rather than in defence (Herms \& Mattson 1992), even though colonizing a poor soil and in a harsh environment. Likewise, the fact that this is an Asteraceae species, compared with Melastomataceae species, could implicate in phylogenetic constraints to anatomic evolution towards a more efficient defensive system based on leaf deterrence. Such phylogenetic explanation needs further analyses.

Some ecophysiologists argue that carbon compounds and low nutritional quality may confound whether selective forces favoured the evolution of defences, and other feeding constraints may reduce herbivory regardless (Loveless 1962, Medina et al. 1990). Conversely, fibres, glandular trichomes and tector emergences represent allocation of carbon compounds into traits that are undoubtedly related to mechanic defence (Salatino 1993, Fernandes 1994, Turner 1994b). The great numbers of distinct defensive structures in cerrado and in high altitude grasslands are suggestive that low nutritional conditions cannot refrain evolutionary forces related to herbivory. As discussed above, the selective pressure of leaf damage can greatly be related to a few specialist insect species.

In addition, the present data shows that anatomic traits are important defences leaf to leaf, but an overall advantage for the plant genotype better defended is hard to quantify. An evolutionarily active arm race between specialist insect herbivores and host plant may always result in imperfect adaptation, and constant change in the mostly important genetically defined phenotype traits present in a population (Hamilton et al. 1990). A long-term interaction with insects, which is expected in such an old ecosystem such as the cerrado and high altitude grasslands of southern Brazil (Rizzini 1997, Mendonça Jr. 2001), could explain the ecological importance of such adaptations in sclerophyllous plants.

Acknowledgments - We thank Phyllis Coley for the useful comments on the development of this project and Margaret D. Lowman for reviewing the manuscript. Fapemig (process CRA 85099/01) has funded the project, and Julio Antônio Lombardi and João Semir for identification of species.

\section{References}

BERNAYS, E., DRIVER, G.C. \& BILGENER, M. 1989. Herbivores and plant tannins. Advances in Ecological Research 19:263-302.

COLEY, P.D. 1983. Herbivory and defensive characteristics of tree species in a lowland tropical forest. Ecological Monographs 53:209-233. 
COLEY, P.D. \& AIDE, T.M. 1991. A comparison of herbivory and plant defences in temperate and tropical broad-leaved forest. In Plant-Animal Interactions: evolutionary ecology in tropical and temperate regions (P.W. Price, T.M. Kewinsohn, G.W. Fernandes \& W.W Benson, eds.). John Wiley and Sons, New York, p.25-49.

COLEY, P.D. \& BARONE, J.A. 1996. Herbivory and plant defences in tropical forests. Annual Review of Ecology and Systematics 27:305-335.

CRAWLEY, M.J. 1997. Plant ecology. Blackwell Science Ltd, Oxford.

ESAU, K. 1977. Anatomy of seed plants. John Wiley and Sons, New York.

FAHN, A. 1990. Plant anatomy. $4^{\text {th }}$ ed. Pergamon Press, Oxford.

FAHN, A. \& CUTLER, D.F. 1992. Xerophytes. Encyclopedia of plant taxonomy. Gebrüder Borntraeger, Berlin.

FEENY, P. 1970. Seasonal changes in oak leaf tannins and nutrients as a cause of spring feeding by winter moth caterpillars. Ecology 51:565-581.

FEENY, P. 1976. Plant apparency and chemical defence. In Biochemical interations between plants and insects (J.B. Harborne, ed.). Recent advances in Phytochemistry. Academic Press, London, p.163-266.

FERNANDES, G.W. 1994. Plant mechanical defences against insect herbivory. Revista Brasileira de Entomologia 38:421-433.

FERNANDES, G.W. \& PRICE, P.W. 1988. Biogeographical gradients in galling species richness: tests of hypotheses. Oecologia 76:161-167.

FOSTER, A.S. 1953. Techniques for the study of venation patterns on the leaves of angiosperms. Proceedings $7^{\text {th }}$ International Congress of Botany. Stockholm (1950).

GALVÃO, M.V. \& NIMER, E. 1965. Clima. In Geografia do Brasil. Grande região Leste. (IBGE, ed.). IBGE, Rio de Janeiro, p.91-139.

GERSHENSON, J. 1984. Changes in the levels of plant secondary metabolite production under water and nutrient stress. Recent Advances in Phytochemistry 18: 273-320.

GIULIETTI, A.M., MENEZES, N.L., PIRANI, J.R., MEGURO, M. \& WANDERLEY, M.G.L. 1987. Flora da Serra do Cipó, Minas Gerais: caracterização e lista das espécies. Boletim de Botânica 9:1-153.

HAMILTON, W.D., AXELROD, R. \& TANESE, R. 1990. Sexual reproduction as an adaptation to resist parasites (a review). Proceedings of the National Academy of Science - Evolution 87:3566-3573.

HANDRO, W., CAMPOS, J.F.B.M. \& OLIVEIRA, Z.M. 1970. Sobre a anatomia foliar de algumas Compostas dos campos rupestres. Ciência e Cultura 22:107-126.

HASLAM, E. 1988. Plant polyphenols (syn. vegetable tannis) and chemical defence - a reappraisal. Journal of Chemical Ecology 14:1789-1805.
HERMS, D.A. \& MATTSON, W.J. 1992. The dilemma of plants: to grow or defend. Quarterly Review in Biology 67:283-335.

HICKEY, L.J. 1979. A revised classification of the architecture of dicotyledonous leaves. In Anatomy of the dicotyledons (C.R. Metcalfe \& L. Chalk, eds.). Clarendon Press, Oxford, p.25-39.

HOWE, H.F. \& WESTLEY, L.C. 1988. Ecological relationships of plants and animals. Oxford University Press, New York.

JOHANSEN, D.A. 1940. Plant microtechnique. McGrawHill Company, New York.

LIMA, E.L. 1991. Medida e forma em geometria comprimento, área, volume e semelhança. Segrac Sociedade Editora e Gráfica de Ação Comunitária, Belo Horizonte.

LOVELESS, A.R. 1962. Further evidence to support a nutricional interpretation of sclerophylly. Annals of Botany 26:551-561.

LOWMAN, M.D. 1995a. Herbivory in Australian forests - a comparison of dry sclerophyll and rain forest canopies. Proceedings of the Linnaean Society 115:77-87.

LOWMAN, M.D. 1995b. Herbivory as a canopy process in rain forest trees. In Forest canopies (M.D. Lowman \& N.M. Nadkarni, eds.). Academic Press, San Diego, p.431-455.

LOWMAN, M.D. \& BOX, J.D. 1983. Variation in leaf toughness and phenolic content among five species of Australian rain forest trees. Australian Journal of Ecology 8:17-25.

LUCAS, P.W, TURNER, I.M., DOMIMY, N.J. \& YAMASHITA, N. 2000. Mechanical defences to herbivory. Annals of Botany 86:913-920.

MADEIRA, J.A., RIBEIRO, K.T. \& FERNANDES, G.W. 1998. Herbivory, tannins and sclerophylly in Chamaecrista linearifolia (Fabaceae) along an altitudinal gradient. Brazilian Journal of Ecology 2:24-29.

MEDINA, E., GARCIA, V. \& CUEVAS, E. 1990. Sclerophylly and oligotrophic environments: relationships between leaf structure, mineral nutrient content, and drought resistance in tropical rain forest of the upper rio Negro region. Biotropica 22:51-64.

MENDONÇA JR, M.S. 2001. Gall insects diversity patterns: the resource synchronisation hypothesis. Oikos 95:171-176.

MOLES, A.T. \& WESTOBY, M. 2000. Do small leaves expand faster than large leaves, and do shorter expansion times reduce herbivore damage? Oikos 90:517-524.

MONTEIRO, W.R., CASTRO, M.M. \& GIULIETTI, A.M. 1985. Aspects of leaf structure of some species of Leiothrix Ruhl. (Eriocaulaceae) from Serra do Cipó (Minas Gerais, Brazil). Revista Brasileira de Botânica 8:109-125.

PANDA, N. \& NAUSH, G.S. 1995. Host plant resistance to insects. CAB International, Wallingford. 
PRICE, P.W. 1984. Insect ecology. John Wiley and Sons, New York.

PRICE, P.W. 1991. The plant vigor hypothesis and herbivore attack. Oikos 62:244-251.

PYYKKO, M. 1966. The leaf anatomy of East Patagonian xeromorphic plants. Annales Botanici Fennici 3:453622.

REICH, P.B., UHL, C., WALTERS, M.B. \& ELLSWORTH, D.S. 1991. Leaf lifespan as a determinant of leaf structure and function among 23 Amazonian tree species. Oecologia 86:16-24.

RIBEIRO, S.P. 2003. Insect herbivores in the canopies of savannas and rainforests. In Arthropods of tropical forests: spatio-temporal dynamics and resource use in the canopy (Y. Basset, V. Novotny, S.E. Miller \& R.L. Kitching, eds.). Cambridge University Press, Oxford, p.348-364.

RIBEIRO, S.P, PIMENTA, H.R. \& FERNANDES, G.W. 1994. Herbivory by chewing and sucking insects on Tabebuia ochracea. Biotropica 26:302-307.

RIBEIRO, S.P, CARNEIRO, M.A. A. \& FERNANDES, G.W. 1998. Richness and distribution of free-feeding insect herbivores in Serra do Cipó, an old quartzite Brazilian mountain. Journal of Insect Conservation 2:1-12.

RIBEIRO, S.P., BRAGA, A.O., SILVA, C.H.L. \& FERNANDES, G.W. 1999. Leaf polyphenols in Brazilian Melastomataceae: sclerophylly, habitats, and insect herbivores. Ecotropica 5:137-146.

RIBEIRO, S.P., BORGES, P.P. \& GASPAR, C. 2003. Ecology and evolution of the arborescent Erica azorica (Ericaceae). Archipelago 1:41-53.

RIBEIRO, S.P., BORGES, P.A.V., GASPAR, C., MELO, C., SERRANO, A.R.M., AMARAL, J., AGUIAR, C., QUARTAU, J.A. \& ANDRÉ, G. 2005. Canopy insect herbivores in the Azorean Laurisilva forests: key host plant species in a highly generalist insect community. Ecography 28:315-330.
RINKER, H.B. \& LOWMAN, M.D. 2004. Insect herbivory in tropical forests. In Forest canopies (M.D. Lowman \& H.B. Rinker, eds.). Elsevier, Sarasota, p.359-386.

RIZZINI, C.T. 1997. Tratado de fitogeografia do Brasil: aspectos ecológicos, sociológicos e florísticos. Âmbito Cultural Editora, Rio de Janeiro.

SALATINO, A. 1993. Chemical ecology and theory of oligotrophic scleromorphism. Anais da Academia Brasileira de Ciências 65:1-13.

SASS, J.E. 1951. Botanical microtechnique. $2^{\text {nd }}$ ed. The Iowa State College Press, Ames.

SCHOWALTER, T.D. \& LOWMAN, M.D. 1999. Forest herbivory: insects. In Ecosystems of disturbed ground (L. Walker, ed.). Elsevier, Amsterdam p.253-269.

SOUSA, H.C. 1997. Estudo comparativo de adaptações anatômicas em órgãos vegetativos de espécies de Lavoisiera DC. (Melastomataceae) da Serra do Cipó, MG. Tese de doutorado, Universidade de São Paulo, São Paulo.

TURNER, I.M. 1994a. A quantitative analysis of leaf form in woody plants from the world's major broad-leaved forest types. Journal of Biogeography 21:413-419.

TURNER, I.M. 1994b. Sclerophylly: primarily protective. Functional Ecology 8:669-675.

WHITHAM, T.G. 1983. Host manipulation of parasites: within-plant variation as a defence against rapidly evolving pests. In Variable plants and herbivores in natural and managed systems (R.F. Denno \& S. McClure, eds.). Academic Press, New York, p.15-41.

WHITHAM, T.J. \& SLOBODCHIKOFF, D. 1981. Evolution by individuals, plant-interations, and mosaic of genetic variability. The adaptative significance of somatic mutation in plants. Oecologia 49:287-292.

WOODMAN, R.L. \& FERNANDES, G.W. 1991. Differential mechanical defence: herbivory, evapotranspiration, and leaf-hairs. Oikos 60:11-19.

ZAR, J.H. 1996. Biostatistical analysis. $4^{\text {th }}$ ed. Prentice Hall, Upper Saddle River. 